N. ${ }^{\circ} 58 \quad$ Abril-Junho

1964

Vol. XXVIII -- REVISTA DE HISTÓRIA -- Ano XV

\title{
CONFERÊNCIA
}

\section{O POVO ARMÊNIO E SUA EVOLUÇÃO HISTORICA.}

A finalidade das Conferências sôbre os assuntos Orientais (*) é de ilustrar e orientar, de maneira prática, o público a respeito da cultura e da história dos povos do Oriente em geral, cujos filhos, desde tempos remotos, começaram a povoar o Brasil e no momento atual vivem e compartilham os destinos do país.

Um dêstes povos do Oriente Próximo é o armênio, cuja origem e evolução histórica vamos expor de modo sucinto.

Nenhum dos povos sabe com precisão cronológica o "como" e o "quando" da sua origem. A origem de todos está envolvida em mitos.

Não vamos dar uma aula de história do povo armênio, mas expor, sob a luz dos dados históricos, a sua origem e a sua evolução através dos séculos. E para tornar mais clara, no seu complexo, esta exposição dos fatos históricos, relacionados com os respectivos documentos, dividimos a nossa palestra em seis pontos principais.

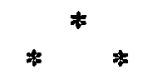

\section{I. - OS POVOS DA ARMENIA PRE-HISTÓRICA E DO PERIODO PRE-ARMENIO.}

A posição geográfica da Armênia, històricamente, está sempre ligada aos três rios: Araxes, Eufrates e Tigre, onde, segundo a Bíblia, estava situado o Eden.

(*). - A Seção de Estudos Orientals da Facuidade de Filosofia, Ciências e Letras da Universidade de São Paulo, programou uma série de Conferéncias de divulgação dos seus Cursos. A presente Conferência foi pronunclada no Salão Nobre da Faculdade no dia 28 de outubro de 1963 (Nota da Redação). 
Do período Paleolítico não encontramos, até hoje, nenhum vestígio humano no Planalto Armênio, provàvelmente por ter sido êle uma zona glacial, contràriamente à Mesopotâmia e ao. Egito, que devido a seu clima temperado, foram desde logo habitados por sêres humanos.

Pela primeira vez na História, a cêrca de 1200 anos a. C., no triângulo dos três lagos, Sevan-Van-Urmia, isto é, na mesma posição geográfica da futura Armênia, encontramos um povo, que não é o armênio, um povo do grupo indo-europeu, tendo como vizinhos ao oeste e no centro da Ásia Menor o Império dos hititas, e ao sul, na Mesopotâmia, o Império dos assírios.

Essa região nas inscrições assiro-babilônicas tem diversos. nomes: "Terra de Urartú, Nairí, Khalti" e na Bíblia Sagrada. é chamada de "Reino de Ararat":

a. Terra de Urartú: menciona-se nas inscrições cuneiformes do rei assírio Salmanazar I, em 1270 a. C. (1).

b. Terra de Nairí: nas inscrições cuneiformes do rei assírio Tiglat Palazar I, em 1200 a. C., na descrição de suas guerras contra êste povo, ao oeste e ao norte do lago Van (2).

c. Khalti: êste nome é aquêle com que os povos de Urartú chamavam a si próprios, em homenagem do seu deus principal, de proveniência hitita, cujo nome tinha o significado de "Dono do Mundo". (3) .

d. Ararat, Terra de Ararat, Reino de Ararat: o nome "Ararat" por três vêzes se menciona na Bíblia (Antigo Testamento), cada vez com sentido diverso:

1). - No Gênesis falando do Dilúvio, lê-se:

“A Arca (de Noé) repousou, no sétimo mês, no dia dezessete do mês, sôbre os montes de Ararat" (4).

2). - A segunda expressão é Terra de Ararat: alude ao tempo da dominação dos urartús, quando os dois irmãos, Adramelik e Sanazar, mataram seu pai Senaquerib, rei da Assíria e,

(1). - Cf. Luckenbill, Ancient Records of Assyria and Babylonia. Chicago. 1926, vol. I. págs. $38-40$.

(2). - K. Sarafian, Historia de la Educación en Armenia. Tradução espanho1a. Buenos Aires. 1953, págs. 33-34; H. Thorossian, Histoire de la Litterature Arménienne. Paris. 1951, vide a Introdução.

(3). - Xenofonte, Anabase, texto grego, por Paul Couvreur, 4a. edi, Paris, 1908, Hachette et Cie. Liv. III, cap. 8; Liv. IV, cap. I; Cf. Todos os Historiadores Armếnios antigos; H. Hubschmann, Die altarmenischen Ortsnamen. Estrasburgo, 1904, pág. 200; H. Thorossian, Histoire de la Litterature Arménienne, Paris, 1951, Introduction; H. Asdourian, Hist6ria da Armênia. Buenos Aires, 1947, págs. 18-21.

(4). - Gênesis, VIII, 4 . 


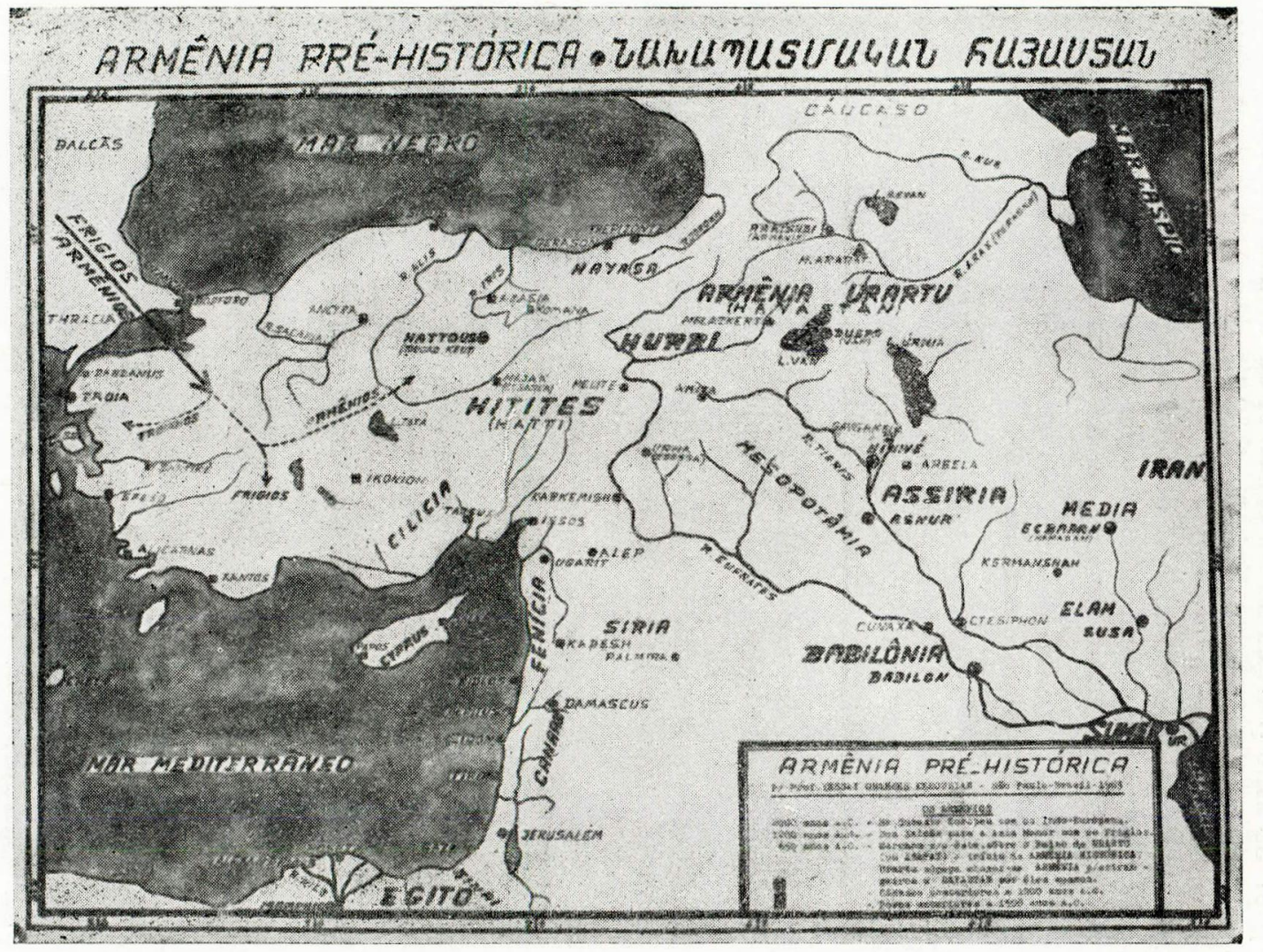

Fig. 1. - A Armênia pré-histórica. 


\section{$-260-$ \\ "fugiram para a Terra de Ararat" (5),}

pedindo asilo político do rei Rusas II do Urartú (680-645 a. C.).

3) : - A terceira expressão da Bíblia é: "Reino dle Ararat; Minni e Askanaz", referindo-se à "Terra de Ararat", dominada agora pelos armênios. O profeta Jeremias, aludindo às nações que participaram da queda de Babilônia, capital do Império babilônico, por obra do rei da Pérsia, Ciro, diz:

\section{"Convocai contra ela (Babilonia) os Reinos de Ara- rat, Minni e Askanaz" (6) .}

A queda de Babilônia teve lugar no ano de 536 a. C., ano em que o rei da Armênia era, provàvelmente, Tigran Yervantian, o de "olhos azuis", que com uma divisão da cavalaria armênia participou da conquista da capital do Império babilônico (7).

A respeito dos nomes Minni e Askanaz, não havendo explicações documentadas, nós o consideramos como apelidos dos povos integrantes da Terra de Ararat. - O nome Askanaz, porém, desde a Antigüidade ( $V$ século: invenção do alfabeto armênio e início da literatura escrita armênia) considerou, pelos historiadores nacionais, como sinônimo do têrmo "armênio".

Agora, dessa documentação histórica podemos concluir seguramente que foram os urartús, chamados "khalti", os habitantes e donos da Pré-Armênia, no periodo precedente à dominação armênia.

Ao enfraquecer o Império dos hititas, entre 1300-1200 a. C. (8), o povo de Urartú declaroù-se independente, mas não sabemos quais foram os primeiros governantes do país.

O reino de Urartú estendia-se do lago Sevan ao sul, até os lagos Van e Urmia.

Sua capital era Dusp - em homenagem ao deus da guerra, de origem hitita, Duspa ou Deshup - que depois foi denominada Van. São dignos de menção as muralhas e as inscrições cuneiformes desta cidade, obras do rei Menuas (810-778 a. C.).

\footnotetext{
(5). - Livro dos Reis, XIX, 37.

(6). - Jeremias, II, 27.

(7). - Mosé Khorenatzi, História da Armênia em armênio. Veneza, última ed. 1955. Traduções em francês, italiano, alemão, russo e latim.

(8). - Ralph Turner, The Great Cultural Traditions. New York-London, 1941, McGraw-Hill Book Co., Inc. 5st ed. vol. I, págs. 225, 234-235; Delaporte (Louis), Les Hittites. Paris. 1936, Imp. Albin Michel, 22 Huyghens, pág. 168 .
} 
A cidade religiosa era Arkishdi, posteriormente denominada Armavir.

A cronologia dos Governadores e dos Reis de Urartú (ou Ararat), desde a fundação dêsse estado e a sua independência (ano c. 1200 a. C.), é incompleta por falta dos documentos. A cronologia documentada, elaborada pelo cientista alemão Lehmann-Haupt, data do ano 885 a. C., porém nem todos autores são concordes acêrca dela, mas todos a aprovam com pequenas variações. Esta cronologia apresenta-se da seguinte maneira $(9)$ :

1). - Lutipris (885-860 a. C.): contemporâneo e adversário de Assurbanibal III da Assíria.

2) . - Aram (860-824 a. C.): adversário de Salmanasar III da Assíria.

3). - Sardur II (835-820? a. C.): dêle temos a primeira inscrição cuneiforme de tipo urartú.

4). - Ispuinis (817-? a. C.): que instalou o seu trono na capital Dusp.

5). - Menuas (810-778 a. C.): filho de Ispuinis, vencedor dos assírios, estendeu o território nacional até a cidade de Melite (Malatia), onde encontrou um povo chamado urmeni (10), construiu as fortificações e as muralhas da capital Dusp, o aqueduto, canalizações e a cidade de Melazkert. Deixou muitas inscrições de tipos urartú e assírio.

6) . - Arkishdis I (778-750 a. C.) : um dos potentes reis de Urartú. Combateu vitoriosamente o rei Salmanasar IV da Assíria, ao norte da cidade de Nínive e ocupou a cidade Amita. Foi. contemporâneo do rei Teglat-Palasar IV da Assíria.

7). - Sardus III (750-733 a. C.).

8). - Rusas I (733-714 a. C.): combateu contra o rei Sargão II da Assíria (11); vencido, suicidou-se.

9) . - Arkishdis II (714-680 a: C.).

10) . - Rusas II (680-645 a. C.): contemporâneo do rei Senaquerib da Assíria (12) .

\footnotetext{
(9). - Lehmann-Haupt, Armenien einst und jetzt. Berlim, 1910, II, 24; Enciclopédia Italiana: v. "Armênia"; H. Asdourian, op. cit., págs. 16-22; H. H. Tchakmakdjian, História da Armênia. Boston, 1917, E. A. Yeran.

(10). - Vide parte $V$, item $A$, explicação 5 .

(11). - Provàvelmente foi o rei Sargáo II da Assíria que destruiu os últimos vestígios dos "pequenos estados hititas" nos árredores da cidade de Karkemish, ao norte da Síria.

(12). - Foi êste rei que concedeu asilo político aos dois irmãos, Adramelik e Sanazar, filhos de Senaquerib. Vide parte I, letra d-1.
} 
11) . - Sardur IV (645-620 a. C.): contemporâneo do rei Assurbanibal (ou Sartanabal, 669-629 a. C.) (13) .

12). - Erimenes (620-605 a. C.).

13). - Rusas III (605-585 a. C.).

O período dos dois últimos reis de Urartú foi provàvelmente o período de transição do trono de Urartú para as mãos dos governadores, que eram de origem armênia.

A língua de Urartú é do grupo indo-europeu, e tem elementos do idioma dos hititas, e é também indo-européia e durante certo período dominou a região.

A eserita era cuneiforme, própria do Urartú, e que se diferencia de forma destacada do cuneiforme assíro-babilônico.

As escavações, feitas por arqueólogos alemães, inglêses e armênios, trouxeram à luz objetos manufaturados, trabalhos finos sôbre metais preciosos, como o ouro, a prata, o bronze, o estanho. Esstes objetos consistem em escudos de bronze enfeitados, enfeites metálicos, vasos e recipientes de terracota, tintos em verniz vermelho. Esstes objetos conservam-se nos museus de Londres e de Berlim (14).

No museu da cidade de Kirovagan, na Armênia, conservam-se uma espada prateada, anel de prata, brincos de ouro, bandeija de bronze, etc.

Estes objetos são indícios de um nível bastante progressivo da civilização dos povos do Urartú. Esta tem um lado curioso que consiste na sua semelhança com a civilização dos povos etruscos da Etrúria, na Itália meridional, cuja origem permanece indecifrável até hoje aos arqueólogos (15).

Urartú, pela sua posição geográfica num planalto montanhoso, foi um país difìcilmente dominado, sempre permaneceu como uma perene ameaça para o seu vizinho do sul - o império assírio da Mesopotâmia -- e por isso nunca faltaram as guerras entre êles (16), devido às rivalidades e guerras contínuas entre si e com os povos vizinhos, alguns dos quais se tinham recentemente instalado nas suas proximidades, nas duas capitais, respectivamente Dusp de Urartú e Nínive da Assíria, e por isso acabaram por se enfraquecer reciprocamente.

(13). - Assurbanibal ou Sartanabal, último rei poderoso da Assíria, que organizou uma biblioteca com inscrições cuneiformes em tabletes de argila, que contém também a história de Urartú ou Ararat.

(14). - Enciclopédia Britânica e Italiana, vide verbetes: Urartú e Armênla. H. Asdourian, op. cit., págs. 21-22.

(15). - Enciclopédia Italiana, vide Armênia.

(16). - R. Turner, op. cit., I, pág. 243. 
Era o tempo das grandes emprêsas conquistadoras e dos grandes movimentos emigratórios dos novos povos indo-europeus e das "gentes do mar", que nos periodos precedentes (c. de 1200 a. C.), passando dos Balcấs e da Trácia para a Ásia Menor, instalaram-se nas ilhas do mar Egeu e nos diversos pontos da Asia Menor, período em que a potência dominadora da Asia Menor, o Império dos hititas, encontrava-se em decadência e declínio (17).

Grupo importante dêsses povos eram os frígios, os armênios e os troianos, povos da mesma família indo-européia (18). Por tempo indeterminado, quase 500 anos, êstes três povos viveram quase juntos, os frígios de preferência na parte litoral e ocidental da Ásia Menor, fundando aí a Frígia; os armênios na parte central e litoral do norte, enquanto que os troianos instalaram-se na extremidade litorânea do estreito de Dardanelos, onde fundaram a famosa cidade de Tróia (19) .

Os armênios, devido suas relações comerciais e sociais, estavam em contínuo contacto com os hititas e com os urartús, isso mais ou menos em 650 a. C.

O Império dos hititas estava desaparecendo como "estado único", o Império assírio da Mesopotâmia estava enfraquecido, e ao oeste o Reino de Urartú chegava ao fim de suas fôrças, quando os armênios, em procura de um lugar mais seguro para a própria defesa, separaram-se dos frígios e avançaram para o oeste, sôbre o Reino de Urartú, que já conhecima e se fixaram às margens do rio Araxe (Yeraskh), dominaram a população local, do grupo indo-europeu de "tipo alpino" e dissolveram-se entre êles. Desta fusão de vencedores e vencidos, etnològicamente idênticos, resultou um tipo nôvo, bem caracterizado, o qual começou a ser chamado de tipo armenóide, pelo elemento predominante armênio que dêste momento em diante ficou sendo o representante oficial dêste tipo.

Esta fusão dos povos procedeu-se normalmente, como uma transferência natural de uma herança, de um para outro, tanto que o nome Urartú, mesmo depois de ter deixado de existir, continuou a ser sinônimo de Armênia e Ararat. A êste respeito vide a inscrição trilíngüe de Behistun, de Dario I, rei da Pérsia, do ano 515 a. C. (20).

(17) . - R. Turner, op. cit., I, págs. 224-227, 232, 237; Delaporte, op. cit., pág. 168.

(18). - R. Turner, op. cit., I, págs. 236-237.

(19). - R. Turner, op. cit., 1 , págs. 236-237.

(20). - Vide $\mathrm{V}$ parte, 1 . 
Faltam documentos, mas o fato é que, desde daquela época, isto é, mais ou menos 620 anos a. C., o antigo Reino de Urartú. começou a ser chamado de Armênia pelos estrangeiros e Hayastan pelos indígenas, o qual tornou-se a pátria geográfica e. histórica do povo armênio.

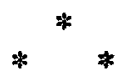

\section{II. - A ORIGEM E O GRUPO RACIAL ARMENIO.}

Os etnólogos e os antropólogos concordam com o fato, històricamente e cientificamente provado, que os antigos povos da Asia Menor, hititas, urartús, frígios, armênios, troianos, etc., pertencem ao mesmo grupo racial indo-europeu, e tiveram o mesmo lugar comum de origem, isto é, a vasta região que se estende entre os mares Báltico e Cáspio, que foi a pátria comum dos povos indo-europeus em geral.

Os armênios, pelos costumes e língua, têm uma semelhança particular com o povo frígio. Sua vida comum nos Balcãs, seu itinerário emigratório, sempre juntos, justificam a nossa afirmação. Alguns lingüistas afirmam existir uma ligação entre as palavras "Asdwadz" em armênio e "Aspasias" em frígio, que significam "deus" (21).

Ássim, na regiâo dos Balcãs, em 2000 a. C., frígios e armênios viveram juntos; em 1200 a. C. passam juntos para a Ásia Menor, de onde os armênios marcham para o este, sôbre o Reino de Urartú.

Vamos apresentar agora algumas conclusões autênticas dos historiadores antigos e dos homens de ciência moderna, mundialmente conhecidos, a respeito do lugar de origem e do grupo. racial do povo armênio.

\section{Autores Antigos.}

1). - Hexódoto (480-425?): grego, o "pai da História", considera os armênios como parentes dos frígios, nativos da Europa e vivendo com os macedônios. No exército do rei Xerxes da Pérsia, quando êste guerreava os gregos, achavam-se entre os soldados mercenários também os frígios e armênios, que vestiam os mesmos trajes, usavam as mesmas armas e. eram dirigidos pelo mesmo comandante (22) .

(2i). - H. Asdourian, op. cit., pág. 29.

(22). - Heródoto, História, livro 7, séc. 7. Trad. inglêsa de C. C. Macaulay, Londres, 1904, Macmillan \& Co.; K. Sarafian, op. cit., págs. 34-35; H. Thorossian, op. cit., pág. 19. 
2). - Xenofonte (430-360? a. C.): grego, general e historiador. Esteve em 400 a. C. no comando de 10.000 mercenários gregos por conta de Ciro-o-Môço, partiu da cidade de Sartiké (Frígia) para a Mesopotâmia, contra o rei Artaxerxes da Pérsia. Perto da cidade de Cunaxa, os gregos foram derrotados e começaram a sua famosa retirada, disciplinada e cheia de aventuras. Xenofonte escreveu a história dêsse acontecimento no seu livro Anabasis (palavra grega que significa "retirada"). Durante esta famosa operação militar, na passagem pela Armênia, os gregos tiveram cordial acolhimento, abundância de comidas e bebidas. Xenofonte exprime também a respeito dos armênios, as mesmas opiniões de Heródoto (23).

3). - Estrabão (c. 63 a. C.-21 d. C.): grego, natural da cidade de Amásia, geógrafo da época clássica. Confirma as opiniões dos escritores antigos a respeito da emigração armênia da Europa para a Asia Menor (24).

\section{Autores Modernos mais notáveis.}

\section{4). - D. G. Brinton:}

"Os armênios são uma ramificação de origem trácia, que ocuparam territórios na Asia Menor, cêrca de 700 anos a. C." (25).

\section{5) . - W. Z. Ripley:}

"Há uma semelhança surpreendente entre o tipo armenóide e as nossas raças alpinas da Europa ocidental... A importância do grupo armenóide deriva do fato que, junto com tipo caucásico, è o único laço de uniāo entre - tipo racial alpino da Europa ocidental e os tipos da Ásia ocidental... e, sem dúvida, a continuação da raça alpina através da Ásia Menor" (26).

6). - Von Luschan:

"A raça alpina da Europa central está, sem dúvida. relacionada, de qualquer maneira, com os povos arme-

(23). - Xenofonte, Anabasis, livros III-IV, texto grego, com comentários de Paul Couvreur, 4a. ed. Paris, 1908, Hachette e Cie.; H. Asdourian, op. cit., págs. 29-30, 36-38; H. Thorossian, op. cit., pág. 19; H. H. Tchakmakdjian, História da Armênia, Boston, 1917, E. A. Yeran, pág. 66.

(24). - Vide a tradução inglêsa, com anotações de William Heinemann, The Geography of Strabo, New York, J. P. Putman's Sons, London, 8 vols. Vide vol. V,' pág. 333, livro 10; K. Sarafian, op. cit., págs. 35 e 350; H. Thorossian, op. cit., pág. 19; R. Turner, op. cit., II, 971.

(25). - D. G. Brinton, Race of Peoples, New York, 1890, 167; K. Sarafian, op: cit., pág. 36.

(26). - W. Z. Ripley, The Races of Europa. New York, 1900, pág. 448; K. Sarafian, op. cit., pág. 36 . 
nóides da Ásia Menor, e não é fácil determinar a priori, se os hititas vieram da Europa central ou se a raça alpina procede da Ásia ocidental" (27).

7). - A. C. Haddon: professor de Antropologia na Universidade de Cambridge (Inglaterra), identifica os armênios com a raça alpina de Cevennes, região montanhosa ao centro-sul da França, e com o grupo dinárico dos Balcãs (28) .

8). - Roland B. Dixon: professor da Universidade de Harvard e uma das maiores autoridades no campo antropológico, chega à conclusão, que

"o povo armênio se formou pelo amálgama do antigo grupo alpino original com o grupo emigrante indo-europeu dos frígios. O resultado desta amálgama foi o tipo armenóide, representado pelo povo armênio" (29).

9) . - Franz Boas: professor da Universidade de Colúmbia dos Estados Unidos.

"Os armênios são tão semelhantes aos povos que chamamos alpinos que, da minha parte, se estiverem presentes cem armênios, não seria possível decidir se todos são armênios, ou europeus da Europa sul-oriental, entre êles pnderiam haver suiços, austriacos do sul, italianos, espanhóis e franceses, e assim sucessivamente" (30).

10) . - Carleton Stevens Leon: professor da Universidade de Harvard. Descrevendo as características raciais dos armênios, os classifica como a

"divisão alfina braquicéfala da raça branca" (31).

11). - A. Giuseppe Sergi: famoso antropólogo italiano, conclui que

"os armênios e os povos do Cáucaso são do mesmo grupo, ao qual pertencem os povos da Europa".

(27). - Von Luschan, The Early Inhabitants of Western Asia and Ireland, in "Journal of the Royal Anthropological Institute of Great Britain", 1911, vol. 41, pág. 243; IK. Sarafian, op. cit., pág. 36 .

(28). - A. C. Haddon, The Races of Man and their Distribution, 1929; K. Sarafian, op. cit., págs. 36-37.

(29). - Roland B. Dixon, The racial History of Man. New York-London, 1923, Charles Scribner's Sons, págs. 317-319; K. Sarafian, op. cit., pág. 37.

(30). - Franz Boas, General Anthropology, 1938.

(31). - Carleton Stevens Leon, The Races of Europa, págs. 625-629. 
Segundo êste cientista, todos os povos da Ásia Menor, do mar Cáspio até a Finlândia, pertencem a um único tipo racial, que êle chama "Neoanthropos sôbre notanthropos" (32).

12) . - René Grousset: historiador francês e membro da Academia Francesa, diz:

"Contràriamente às aparências geográficas, a Armênia está na Europa... Por sua raça indo-européia... O espirito da história da Armênia reside na sua língua indoeuropéia e no seu caráter indo-europeu" (33).

13) . - Ardachés Abeghian: cientista armênio da Universidade de Berlim, que escreveu uma série de artigos sôbre o assunto, quando no períolo nazista da Alemanha de Hitler surgiram problemas raciais do arianismo com conseqüências políticas. A conclusão dos seus estudos foram, que

"o tipo nórdico é comum entre os armênios e em algumas regiões da Armênia existe uma proporção maior de armênios com olhos azuis do que foi notado pelos antropólogos europeus. Os armênios são de raẹa ariana".

As conclusões do cientista foram decisivas para a classificação racial e para a sorte dos seus patrícios naquele período (34) .

Resumindo os dados da História e da ciência lingüísticoantropológica moderna, podemos concluir definitivamente o problema racial do povo armênio, afirmando: a) sua origem européia; b) seu caráter indo-europeu; c) sua classificação como "tipo alpino" da Europa; e d) representante oficial do "tipo armenóide" (35).

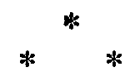

\section{III. - O ITINERARIO MIGRATÓRIO DO POVO ARMENIO.}

Este capítulo está intrìnsecamente ligado ao precedente onde, tratando das questões da origem e de raça do povo armênio, virtualmente já esboçamos o assunto.

\footnotetext{
(32). - A. Giuseppe Sergi, L'uomo, le origini, l'antichità, le variazioni e la distribuzione geografica. Roma, 1911; R. Turner, op. cit., I, págs. 224-227, 232, 237.

(33). - René Grousset, Histoire de l'Arménie, des origines à 1701, Paris, 1947; H. Thorossian, Histoire de la Litterature Arménienne, Paris, 1951.

(34). - Ardachés Abeghian, Armeni Ariani, ed. HIM, Roma, 1939, XVII, págs. 26-36.

(35). - R. Turner, op. cit., I, págs. 46-54.
} 
Agora vamos delinear, em três fases, de forma cronológica e topográfica, o itinerário migratório dêsse povo, indicando possìvelmente as rotas e as regiões que serviram para êste itinerário, começando do lugar de origem até o ponto final, onde foi criada a pátria final dêsse povo.

1a. fase: 2000 anos a. $C$.

Na vasta região entre o mar Báltico e o mar Cáspio, frígios, armênios e troianos viviam juntos com as tribos gregas: aqueus, dórios e trácios. E' difícil determinar com exatidão topográfica o lugar certo desta permanência, o mais provável é o sudeste europeu, do vale do Danúbio até a região balcânica, baseando-se a nossa afirmação em dois dados: a) referências dos historiadores gregos (Heródoto, Xenofonte, Estrabão, que citam os nomes de Macedônia e de Trácia, como região de moradia dos frígios e dos armênios) e b) semelhanças entre a civilização dos povos da Etrúria, na Itália meridional, e a civilização dos povos de Urartú, originário também da Europa e residente na Armênia, no período pré-armênio.

Desta massa de gente, foram as tribos gregas as primeiras a deslocar-se antes de 1200 anos a. C., os aqueus e dórios na direção da Grécia e os trácios rumo à Trácia (36).

\section{2a. fase: 1200 anos a. $\mathrm{C}$.}

Período de grandes movimentos migratórios em geral, para a Asia Menor e para o mar Egeu, e declínio do Império dos hititas no centro da Asia Menor (37).

Frígios, armênios e troianos passam pela Trácia rumo à Asia Menor. O ponto de passagem pode ser uma das extremidades do mar de Mármara, ou o estreito de Dardanelos ou ainda o do Bósforo.

Os frígios se instalam no litoral do mar Egeu e no interior da Ásia Menor; os troianos no litoral do mar Ëgeu, na embocadura do mar de Mármara, onde fundaram, c. de 1185 a. C. (38), a cidade-fortaleza de Tróia (ou Ilion), que se tornou famosa na História devido a guerra de dez anos com os gregos e pela obra-prima poética de Homero (Ilíada). Elementos ar: mênios participaram dessa guerra, o que faz supor uma relação de parentesco entre os dois povos, troiano e armênio (39).

(36). - R. Turner, op. cit., I, págs. 235-237.

(37). - R. Turner, op. cit.., I, págs. 224-227, 232, 237.

(38). - R. Turner, op. cit., I, pág. 237.

(39). - Vide M. Khorenatzi, Históri ada Armênia. 
Os armênios instalaram-se ao norte da Ásia Menor e no vale dos rios Alis e Iris.

Neste período outros povos, chamados de gentes do mar, procedentes da Acáia (40), instalaram-se nas ilhas do mar Egeu, onde, na grande ilha de Creta, capital Cnossos, já existia desde tempos remotos (3000-1600 anos a. C.) a civilização florescente dos minoanos (41).

3a. fase: 650 anos a. C.

As guerras contínuas, para conquistas de terras, devoraram os povos. Era o tempo da fôrça e do predomínio. O Império dos hititas estava desaparecendo, o Império dos assírios e o Reino de Urartú no fim de suas fôrças. Nesta situação confusa, o povo armênio, em procura de uma posição geogràficamente mais segura, continuou a sua marcha migratória na direção das alturas de Ararat, Reino de Urartú, seguindo os cursos dos rios Alis e Iris, e as rotas ao pé dos montes de Khaltik. Êste itinerário dava possibilidades de encontrar cidades para o abrigo e para o abastecimento da população emigrante. No seu longo caminho os armênios fundaram cidades (42), passaram pela cidade de Hattous (43), que serviu de capital ao Império dos hititas.

Chegados, enfim, aos confins do Reino de Urartú, fixaram-se nas margens ocidentais do rio Arax (Yeraskh) e aí começou a luta pelo domínio da Terra de Ararat.

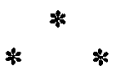

\section{IV. - O COMPARECIMENTO DO POVO E DO NOME ARMENIO NA HISTORIA UNIVERSAL.}

Quais foram os primeiros chefes da nação armênia durante o seu secular caminho migratório, que tomaram posse do govêrno e do território de Urartú, que fundaram a pátria histórica dos armênios e como começou a "Terra de Urartú" a chamar-se "Armênia", depois de ser dominada pelos armênios? Sôbre isso nada sabemos. Documentos históricos, contemporâneos dos fatos e documentos locais, não existem.

\footnotetext{
(40). - Antigo nome da Grécia.

(41). $\rightarrow$ R. Turner, op. cit., I, págs. 214-221, 232-234.

(42). - Vide M. Khorenatzi, a cidade Amásia foi fundada por um descendente de Hayk, de nome Amásia.

(43). - Atual Boghaz-Keuy.
} 
As primeiras noções, juntamente com os fatos lendários, nós as temos sòmente por via tradicional. Os historiadores armênios, desde o início da literatura nacional, no $\mathrm{V}$ século $\mathrm{d}$. C., bașeados nessas tradições e talvez em documentos que não chegaram às nossas mãos (44), admitem unânimemente que o primeiro chefe e fundador da nação foi o general Hayk. Ele e seus companheiros, todos filhos e descendentes da sua geração: Armenak, Aramayis, Amasia, Baruyr, Khegham e outros, foram os chefes da nação armênia, antes e depois de entrarem no território de Urartú-Ararat (45).

Aos 615 a. C. o nôvo Estado armênio era tributário do seu potente vizinho do sudoeste, o reino dos persas.

No ano 612 a. C., o rei Baruyr da Armênia com seu exército cooperou com o rei da Média, Kiaksar, para a queda de Nínive, capital do Império dos assírios.

Vamos ver o que dizem os documentos históricos, a respeito do povo e do nome armênio:

1). - O primeiro documento histórico referente ao Reino de Ararat dos armênios é a Bíblia, onde o profeta Jeremias, falando a respeito das nações aliadas do rei Ciro da Pérsia na operação da queda de Babilônia, escreve:

"Convocai contra ela (Babilônia) os reinos de Ararat, Minni e Askanaz" (46).

Isto aconteceu no ano 536 a. C. e foi o rei da Armênia, Tigran Yervantian, que com uma divisão da cavalaria armênia, cooperou com o rei Ciro para a destruição do gigantesco baluarte do Império babilônico.

2). - O documento mais importante é a famosa inscrição trilíngüe de Behistun, do rei Dario I dos persas, no ano 515 a. C., onde pela primeira vez na História aparece o nome Armênia (Armínia).

E' uma inscrição cuneiforme, em três línguas, iraniana-yelamiana-babilônica, que eram faladas respectivamente nas três grandes cidades do vasto Império persa: Persépolis, Susa e Babilônia .

$\mathrm{Na}$ coluna de língua babilônica, o nome Armênia das outras duas colunas, está substituído pelo de Urartú, o que é de maior importância.

(44). $\rightarrow$ Vide a este respeito a $\mathrm{V}$ parte.

(45). - Cf. M. Khorenatzi, op. cit.; H. Asdourian, op. cit., pág. 33.

(46). - Jeremias, LI, 27. 


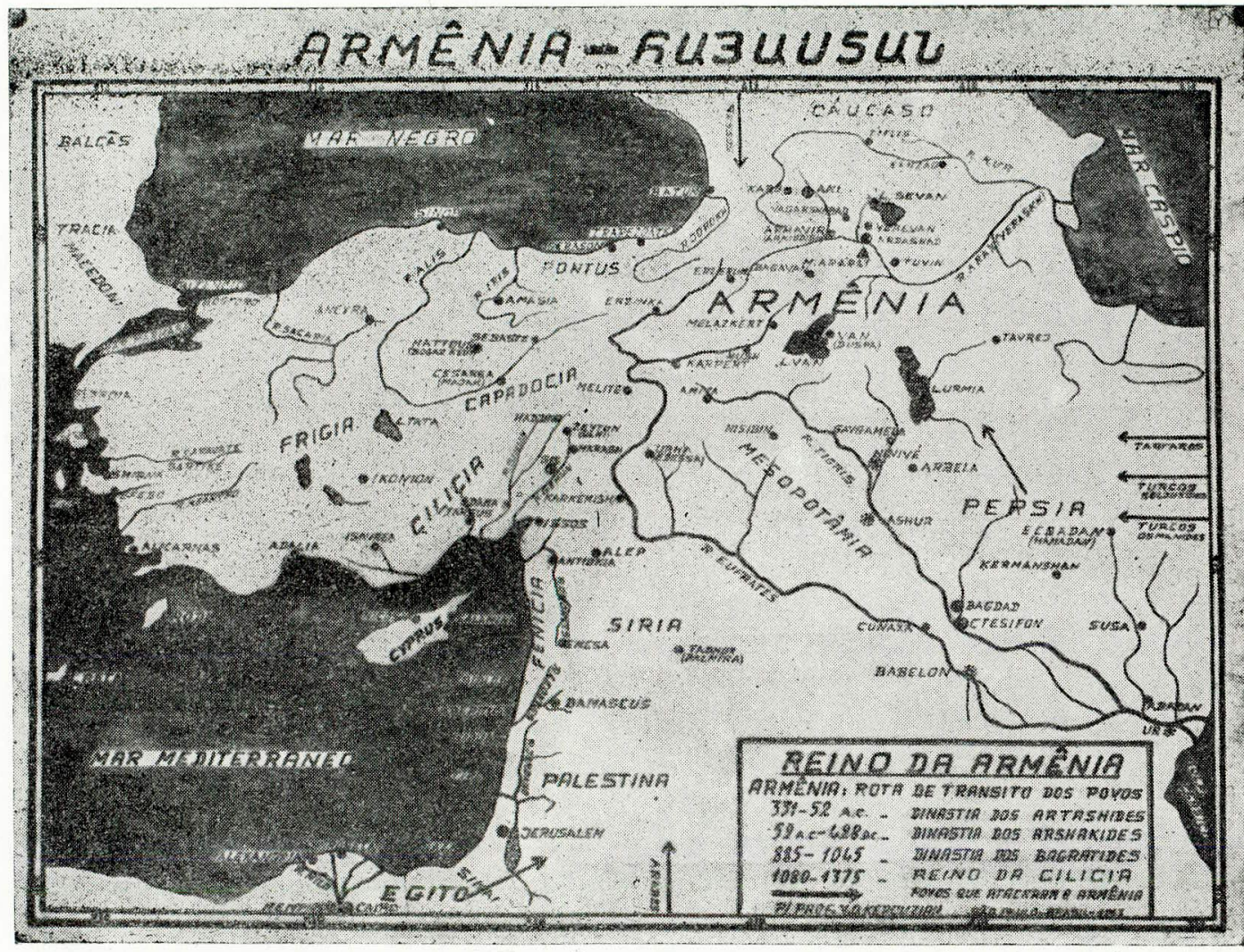

Fig. 2. - o reino da Armệnia, 
Nesta inscrição, que o rei dos persas, Dario I Veshtaspe \{521-485 a. C.) mandou gravar, no ano 515 a. C. em Behistun, localidade cêrca de um quilômetro da cidade de Kermanshah, numa rocha de enormes dimensões (456 metros de altitude) enumera as províncias do seu vasto império e fala de suas guerras contínuas, de sete anos, contra os nove reis, que não queriam pagar tributos, e cujas figuras também estão gravadas nas rochas.

Um dêstes rei era o da Armênia. Para guerrear os armênios, Dario mandou um general armênio, de nome Dadarshish, - qual, apesar de três ataques, foi derrotado e substituído por outro general persa, Varmisha, que no quinto ataque venceu os armênios, ficando a zona sul do país sob contrôle e domínio persa, na época da dinastia dos aquemênidas, do ano 515 ao. 331 a. C. Êsse contrôle, mais do que político, era financeiro, sendo a Armênia obrigada a pagar uma qüota anual de impôsto.

O trecho da inscrição que se refere aos armênios, compõese de cêrca de 220 palavras (47).

O documento de Behistun é de capital importância para a história da Armênia, sob três pontos de vista:

a). - E' pela primeira vez na História que aparece o nome "Armênia", exatamente nas duas colunas da inscrição, na coluna iraniana e yelamiana. $\mathrm{Na}$ coluna de língua babilônica, - nome "Armênia" está substituído pelo de "Urartú". Fato interessante, porque esta substituição dos dois nomes indica a relação histórica e etnológica dos dois povos e a sua identidade territorial.

b). - Que a Pré-Armênia antigamente era Urartú.

c). - Que a Armênia, antes dêstes acontecimentos, era soberana, depois tributária, e para recuperar a sua soberania é que se revoltou (48).

3). - No ano 480 a. C. o rei dos persas, Xerxes, guerreava os gregos. O historiador grego Heródoto, falando sôbre o fato, diz que no exército do Xerxes, compôsto de elementos mercenários, achavam-se também soldados frígios e armênios, que cingiam as mesmas vestes, usavam as mesmas armas e eram dirigidos pelo mesmo comandante (49), como já dissemos.

(47). - H. H. Tchakmakdjian, op. cit., págs. 63-64.

(48). - H. Asdourian, op. cit., págs. 35-36; H. H. Tchakmakdjian, op. cit.., págs. 63-66; R. Turner, op. cit., I, pág. 365.

(49). - Heródoto, liv. 7, séc. 7; H. H. Tchakmakdjian, op. cit., pág. 66; H. Asdourian, op. cit., págs. 30 e 38 . 
4). - O historiador grego Xenofonte (c. 430-360? a. C.), no seu livro "Anabasis" fala da Armênia como país dos armênios. O historiador, na qualidade de general, com 10.000 mercenários gregos, da cidade de Sartiké (Frígia) partira para a Mesopotâmia contra o rei Artaxerxes. Perto da cidade de Cunaxa foi derrotado e começou a retirada (anabasis) grega, rumo ao norte, na direção da Armênia, onde o esfomeado exército grego achou víveres em abundância.

Xenofonte descreve minuciosamente as casas e os hábitos dos armênios e, entre outras coisas, refere-se a um detalhe interessante: que os armênios já naquele tempó conheciam a preparação da cerveja, a conservavam no subsolo, em 'grandes recipientes de terracota e a tomavam por meio de um cánudo $(50)$.

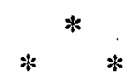

\section{V. — A DERIVAÇÃO DOS NOMES "ARMÊNIA" E "HAY".}

Os armênios chamam-se a si mesmos de Hay e ao seu país de Hayastan. Os' estrangeiros os chamam de armênio e'o país de Armênia. Que origem teriam êstes dois nomes?

Até hoje não temos explicação, histórica e lingüisticamente, satisfatória para poder responder a essas indagações de maneira razoável. Tôdas as respostas são baseadas em suposições e conjecturas.

A falta de documentos históricos é explicável: a) . - - pela destruição completa, na Armênia, de todo vestígio histórico, literário, artístico e réligioso do antigo mundo pagão, levado a 'efeito em $306 \mathrm{~d}$. C.,' pelo fanatismo exagerado da parte daqueles que introduziram oficialmente, no referido ano, o Cristianismo na Armênia (51) e b). - pela falta de escavações arqueológicas satisfatórias na Asia Menor em geral, e na Armênia, em particular, que foi uma encruzilhada das nações, uma rota de trânsito ininterrupto dos povos e dos bárbaros, alvo de guèrras destruidoras, de pilhagens e devastações, e por tudo isso, estas regiões não se tornaram aceśsíveis satisfatòriamente aos cientistas e arqueólogos.

Apesar da falta de documentos, vamos expor aqui as explicações hipotéticas a respeito dos dois nomes:

(50). - Xenofonte, Anabasis, liv. IV, cap. V; vide também II parte.

(51). - Vide os historiadores armênios antigos: Agatângelos, Khorenatzi, Zenob Klag, Faustos Puzant. 


\section{A). - Armênia.}

Como vimos, êste nome aparece pela primeira vez na His-tória na inscrição trilíngüe de Behistun, no ano 515 a. C., onde se menciona, repetidas vêzes, os nomes "Armínia" como. país, e "armínio" como povo. Com o mesmo nome, "Armêniaarmênio" de maneira grega, falam os autores antigos, gregos. e romanos (Heródoto, Estrabão, Xenofonte, Plutarco, Tácito, Cícero, etc.). Com êstes nomes são cunhadas moedas na Armênia, na Grécia e em Roma.

1a. explicação: provém do nome Armenak, que era filho. do general Hayk, hipotético fundador da nação Armênia.

2a. explicação: do nome Aram, bisneto de Hayk.

3a. explicação: do nome Aram, segundo rei, por ordem: cronológica, de Urartú (860-824 a. C.).

4a. explicação: do nome Erimenes, que segundo alguns, foi o penúltimo rei de Urartú (620-605 a. C.), exatamente no. período de transição do reino de Urartú para o dos armênios.

5a. explicação: do nome urmeni de um povo, na região. da cidade de Melite (Malatia), que se menciona numa inscrição do rei Menuas de Urartú (810-778 a. C.).

6a. explicação: do nome Arminius de um dos chefes gre-gos, do lendário feito dos Argonautas.

7a. explicação: da palavra indo-européia ou semítica. "aram"?, que significa "montanha, montanheses, lavrador da, terra", qualificativo dos povos daquela região, eminentemente montanhosa.

8a. explicação: dos nomes Ararat e Minni, duas regiões da Ármênia. Neste caso o nome "Armênia" será formado pela. união da primeira sílaba Ar do primeiro nome, com o segundo nome "Minni".

$$
\text { B) . - Hay . }
$$

Nome exclusivamente usado pelos autores armênios, com que os armênios chamam a si próprios. As diversas explicações a respeito de origem dêste nome são:

1a. explicação: provém do nome Hayk, que segundo as: antigas tradições armênias, foi o filho de Torkom, neto do patriarca Noé, e que foi o primeiro chefe e fundador do estado armênio. Neste caso, a letra final " $K$ " seria o sufixo do. plural em armênio clássico, como o "S" em português. Caso. idêntico verifica-se na explicação tradicional do nome "Ro- 
ma", que vem de "Romulus", tradicional fundador de "Roma" e dos "romanos".

2a. explicação: do nome khalti, apelido dos povos do Urartú ou do Ararat, como êles chamavam a si próprios, em homenagem ao seu principal deus, de proveniência hitita e que significa "dono do mundo". Dêste modo, ao passar o território de Khalti para as mãos dos armênios, seu nome também, com deformações, "Khal, Khay, Hay", passou a determinar os novos senhores do país.

O nome Khalti continuou a existir numa outra região montanhosa da Armênia, Khaltik, para onde se retiraram os povos do Urartú, depois de terem perdido definitivamente a sua independência. Xenofonte fala dessa região chamando-a de Khalibes (52).

3a. explicação: da palavra Pat, de origem indo-européia, que significa "dono, chefe", em armênio pet (bed) (como: varjabed, hayrabed, garabed, kntabed). Com tempo e segundo as regras de transcrição das letras, as letras " $p$ " e " $t$ " se transformaram respectivamente em " $h$ " e " $y$ ", donde resultou o nome Hay, da mesma maneira que as palavras "pater" e "mater" se transformaram em "hayr" e "mayr" em armênio.

Desta maneira, os novos "donos"- do Urartú, os armênios, chamaram a si mesmos pelo nome "pat", que com o tempo transformou-se em hay. Depois, pela junção no fim desta palavra do sufixo de lugar -stan, formou-se o nome Hayastan, isto é, "o lugar de habitação dos Hays" (53).

\section{VI. - QUADRO GERAL DOS DIVERSOS PERIODOS DA HISTORIA DO POVO ARMENIO DO ANO c. 650 a. C. A 1920 d. C.}

Vimos, nos cinco itens anteriores, a parte documentária, referente à origem, raça e emigração do povo armênio, à criação da sua pátria histórica e o seu comparecimento com nome "armênio e hay" na História Universal. E agora, sob forma cronológica e sintética, vamos ver a evolução da sua História, desde os seus primórdios, resumindo o complexo desta evolução, de 2.500 anos contínuos, em seis períodos.

(52). - Xenofonte, Anabasis, liv. 15.

(53). - Como nos nomes: Afkanistan, Belujistan, Pakistan, Tadjikistan, Turkmenistan, etc. 


\section{* \\ 1. Período (tradicional): origem e fundação do Estado armênio (c. 650-330 a. C.).}

Desta fase inicial, da fundação do Estado armênio, com início em cêrca de 650 anos a. C. sabe-se pouca coisa; baseiase ela sobretudo nas obras dos historiadores gregos, pois foi destruída tôda documentação histórica existente na Armênia por ocasião da introdução do Cristianismo nesse país, no ano 304-305 da nossa éra.

Pelos historiadores armênios unânimemente é atribuída ao general Hayk e aos seus descendentes, a ocupação da "Terra de Urartú ou Ararat", a criação do Estado armênio e o seu govêrno.

O primeiro documento, referente a êste período, é a Bíblia, como já vimos, quando fala dos Reinos de Ararat, Minni e Askanaz, por ocasião da queda da capital de Babilônia, Babilon, no ano 536 a. C., por obra de Ciro, rei da Pérsia, ao qual assistiu o rei da Armênia, Tigran Yervantian, com uma divisão da cavalaria armênia (54).

No período que vai de 515-331 a. C., o sul da Armênia encontrava-se sob o contrôle financeiro dos persas da dinastia dos aquemênidas. Este contrôle era, na realidade, uma subordinação nominal, de forma tributária; com 400 talentos de prata anuais (55), conservando o país a sua soberania política:

No ano 480 a. C., no exército do rei Xerxes da Pérsia, achamos soldados frígios e armênios, com as mesmas vestes, as mesmas armas e sob o mesmo comando (56).

Mais tarde, por ordem do rei Ardaxias II da Pérsia, um exército armênio, de 10.000 homens, marchou contra o sátrapa Tatamis da Capadócia.

No ano 4.00 a. C., como já vimos, o historiador e general grego, Xenofonte, com seus 10.000 mercenários gregos, na sua retirada de Cunaxa para o pôrto de Trebizonda, no mar Negro, atravessou a Armênia, encontrando aí a hospitalidade armênia, com "comidas, bebidas; entre as quais a cerveja, bebida com um canudo especial (57).

\footnotetext{
(54). - Jéremias, LI, 27.

(55). - Vide a Inscrição de Behistun, do ano 515 a. C. do rei Dario I; vide IV parte, 2.

(56). - Heródoto, liv. 7, sec. 7 .

(57). - Xenofonte, liv. III-IV.
} 


\section{Período: a dinastia dos artachidas (331 a. C.-52 a. C.) .}

Em 331 a. C., pela primeira vez, a fôrça do Ocidente entra em ação na Asia Menor.

Foi o jovem rei da Macedônia Alexandre Magno que, atravessando o estreito de Bósforo com uma rapidez até então nunca vista, ocupou a região central e o sul da Asia Menor. Com duas batalhas, a de Issos (cidade da Cilícia) e de Arbelas (outubro de 331, na Mesopotâmia) abalou as colossais fôrças de Dario, do vastíssimo Império dos persas, deixando para outra ocasião a ocupação do norte (Capadócia e Ponto) e do oeste (Armênia) da Ásia Menor, preparando-se para abrir um caminho para a India, que foi a sua grande meta. O sonho do jovem monarca, porém, careceu de realização pela sua morte prematura na cidade de Babilônia.

A vitória de Arbelas desagregou o Império dos persas aquemênidas e teve uma feliz conseqüência para a Armênia, que se declarou independente.

Não se conhece o chefe desta independência armênia. Mas o fato é tão evidente que, além de assegurar a própria soberania, a Armênia serviu também como protetora e como "Terra de asilo político" para outros povos.

a). - Em 320 a. C. a Capadócia foi ocupada pelos selêucidas, sucessores de Alexandre Magno. O príncipe herdeiro, Ariarates, pediu asilo político ao rei da Armênia, Artavaztes, e com ajuda dêste, recuperou seu trono no ano 316 a. C.

b). - Em 314 a. C. eclodiu uma luta entre dois generais macedônios e um dêles, Eumenes, vencido pelo seu adversário, procurou asilo na Armênia.

c). - Em 250 a. C. o filho do rei Nigomites da Bitínia, Zilas, por questões de herança com seu pai, fugiu para a Armênia em busca de asilo.

d). - Em 220 a. C. o rei da Armênia, Artavazan, incitava à rebelião os povos que se achavam sob dominação dos selêucidas e ajudava-os.

e). - Em 195 a. C. o famoso general cartaginês Anibal, depois de sua derrota por Cipião-o-Africano, deixou a sua pátria e no seu itinerário errante, foi hóspede do rei da Armênia, Artashês I, e por sua sugestão construiu num ângulo do rei Araxe a nova capital da Armênia: Artashad.

f) . - No período pré-armênio, durante o Reino de Urartú, também aconteceu a mesma coisa: dois irmãos, Adramelik e Sanazar, mataram seu pai, o rei Senaquerib da Assíria, e 
"fugiram para a Terra de Ararat", pedindo asilo ao rei Rusas II de Urartú (680-645 a. C.).

No ano 191 a. C. o rei da Armênia era Artashês I, grande amigo da cultura helenística. Nesse ano, o rei Antíoco III, da dinastia dos selêucidas, foi derrotado pelas fôrças romanas de Cipião-o-Africano, perto da cidade de Magnésia (Ásia Menor). $O$ elemento romano estava rumando para o Oriente.

Artashês I sentiu-se com isso mais livre, organizou a administração estatal do seu govêrno, acertou os confins do país com "pedras limenárias", colocou guarnições nos quatro cantos do país para a sua defesa, estimulou a agricultura, promoveu a arte e a cultura helenística, deu impulso ao comércio com o exterior, inclusive com a China, de onde provinham mercadorias raras, como a sêda, a laca, a pimenta e outras drogas, para serem vendidas ao Ocidente (58). Para coroar a sua obra, construiu em seu nome, como vimos, a nova capital Artashad.

Dêle ficaram diversas inscrições escritas em aramaico (59), que são os primeiros documentos dos reis armênios que chegaram ao nosso conhecimento. E' em homenagem a um tal rei, que o período de 331 a. C.-52 d. C. foi designado pelo nome de dinastia dos artashidas.

Entre seus sucessores, a figura mais eminente é Tigranes II-o-Grantle, "o rei potente da Ásia Menor", segundo a expressão do romano Cícero. Tigranes II, de cultura helenística, homem de caráter forte e reconstrutor, deu esplendor ao seu reino com a expansão da cultura, com a construção das novas cidades, entre as quais a de Tigranakert. Estendeu os confins da Armênia até a Palestina, de onde transferiu tanto elementos judeus, como elementos gregos da Asia Menor, para o desenvolvimento no seu reino do comércio e da cultura das letras e artes.

Tigranes II reinou 40 anos (95-55 a. C.), mas o seu govêrno enfraqueceu-se com a sua idade, ao aparecerem nos confins da Armênia o nôvo elemento perturbador para o Oriente, os romanos, sob o comando dos generais Lúculo e Pompeu que, com suas legiões organizadas venceram as pesadas fôrças do rei

(58). - Fato curioso é o rei Ciro-o-Moço, da Pérsia, procurar comerciantes armênios para o tráfico com a China e o Extremo Oriente. Cf. Revista Hayrenik, 1941, agôsto, n.o 129; H. Asdourian, op. cit., pág. 55.

(59). - Uma escrita de transição, mistura do grego ou fenício com siríaco. 
Tigranes. Pompeu respeitou o velho rei e a começar do ano 50 a. C. a Armênia, em particular a zona ocidental, entrou na esfera da dominação romana e tornou-se aliada de Roma.

Dêste eminente rei, Tigranes II, ficaram moedas de ouro cunhadas com inscrições gregas, um anel de ouro, etc. (60). Ao tempo de Tigranes II, a bandeira armênia ostentava um sol entre duas águias sob fundo vermelho.

Contemporâneo de Tigranes II reinava no Ponto seu genro Mitridades IV, inimigo jurado dos romanos.

Entre os sucessores de Tigranes II, a figura mais nobre é a de seu filho, Artavaztes II (55-34 a. C.), instruído nas letras gregas e que, convidado para ir ao Egito pelo general romano Marco Antônio, foi aí assassinado de maneira covarde por não querer prosternar-se, em sinal de adoração, perante a rainha Cleópatra (61).

3. ${ }^{\circ}$ Período: a dinastia dos arsácidas (62 a. C.428 H. C.).

$\mathrm{O}$ aparecimento dos exércitos romanos e a crescente influência dêstes na Armênia e na Asia Menor em geral, chocou-se com os interêsses dos reis da dinastia dos arsácidas do Império dos partas. Estes, aproveitando-se das rivalidades armênio-romanas, que não faltavam, colocaram no trono vacante da Armênia, Tiridades I, o irmão do rei dos partas. Vagarshes I, apesar da presença da guarnição romana. Os romanos, depois de tentativas de resolver o assunto com mão forte, solucionaram a queixa por via diplomática: o rei da Armênia foi designado pelos partas e Roma enviou a corôa.

No ano 115 a. C., por um decreto do imperador romano 'Trajano, a Armênia foi declarada a mais remota província romana. Para os romanos, os confins do seu Império eram a Ásia Menor, por isso não quiseram perder a aliança da Armênia, como baluarte do seu território contra os ataques dos povos do Oriente Próximo, do bloco iraniano (partas, persas), e mais tarde, dos povos bárbaros procedentes da Asia central. Por estas razões, aumentaram as rivąlidades e a competição entre romanos e persas nela dominação da Armênia, a qual sendo o pomo da discórdia, manteve uma política equilibrada

(60). - Estes objetos conservam-se no museu armênio de São Lázaro, em Veneza.

(61). - o rei Artavaztes II é autor de obras dramáticas e histórias, em língua grega, que não chegaram às nossas mãos. (Cf. Plutarco). Dêle temos moedas com a seguinte inscriçăo em grego: "Rei dos reis Artavaztes"; H. Asdourian ,op. cit., págs. 64, 66, 127 . 
visando sempre o interêsse nacional, única maneira de salvar a sua soberania.

A influência romana começou a diminuir ao subir ao trono da Pérsia, no ano 226, a dinastia dos sassânidas. com Ardashir, homem inteligente, cuja palavra de ordem foi:

"Não existe poder sem armas, nem armas sem dinheiro, nem dinheiro sem agricultura, nem agricultura sem justiça" (62).

No longo período da dinastia dos arsácidas, na maioria das vêzes com reis de origem armênia, desenrolaram-se na Armênia três acontecimentos de capital importância para o povo armênio sob o aspecto religioso, político e cultural.

a). - Religioso: introdução na Armênia do Cristianismo como religião oficial do estado armênio, no ano de 3:04-305, por intermédio do bispo armênio Gregório, apelidado o Iluminador, sendo rei Tiridates III. Foi bem mais tarde que o imperador Constantino, por decreto de Milão instituiu o livre culto do Cristianismo para o Ocidente.

Assim, na História do Cristianismo, pertence à pequena nação armênia, a honra da prioridade de ter adotado, antes de qualquer outro povo do mundo, o Cristianismo como "religião do Estado" (63).

b). - Político: divisão da Armênia em duas zonas de influência, no ano 384, entre Roma (imperador Valério) e a Pérsia (rei Shapur III), para acabar, de uma vez para sempre, com a causa de discórdias entre os dois gigantescos impérios do Ocidente e do Oriente Próximo.

c). - Cultural: invenção do alfabeto armênio, no ano de 405, pelo bispo armênio Mesrob, apelidado Mastodz, reinando Vramshapur (391-414). Durante um período da paz de vinte anos, sem interrupção, a Armênia teve seu ressurgimento nacional, sob o ponto de vista intelectual e cultural, e criou O século do Ouro da sua língua clássica (Krapar).

Logo depois da invenção do alfabeto armênio, foi elaborado um plano de desenvolvimento de âmbito nacional e foram enviados muitos estudantes ao estrangeiro, principalmen-

(62). - R. Turner, op. cit., II, págs. 672-673.

(63). - Ver todos os historiadores armênios antigos, contemporâneos ou quase: Agatângelos, Zenob Klag, Fausto Puzant, Mosé Khorenatzi. Autores estrangeiros: C. Galanus, Historia Armeniae, ecclesiastica et politica. Colônia, 1686; Ed. Dulaurier, Histoire, dogme, tradition et liturgie de l'Eglise Arménienne, Paris, 1857; R. Turner, op. cit., II, págs. 1137-1138; F. Tournebize, Histoire Politique et Religieuse de l'Arménie. Paris, 1910. 
te aos grandes centros de estudos de então: Bizâncio, Atenas, Alexandria do Egito, Antioquia e Edessa. Os jovens, ao voltar para a Armênia, trouxeram consigo manuscritos selecionados da Bíblia Sagrada em língua hebraica, grega e siríaca.

O movimento intelectual começou em todos os setores. Após terem conferido diversos manuscritos, foi traduzida, no melhor armênio clássico, a Bíblia, tradução que por sua beleza e perfeição lingüística, nunca superada depois por parte dos estudiosos franceses e alemães, foi qualificada como a rainha das traduções.

Foram abertas escolas em todos os recantos do país para. a alfabetização do povo, com o "alfabeto nacional". Foram traduzidas obras clássicas gregas e siríacas daquele tempo, obras filosóficas, teológicas e históricas.

O grupo dos estudantes formados no estrangeiro fundou as bases da vida intelecto-cultural das futuras gerações. Um homem de grande talento, Movses Khorenatzi, foi "o pai da história armênia", pesquisando, recolhendo nos arquivos es-. trangeiros e nacionais tudo o que inzeressasse à origem, à história e à cultura da sua nação. Percorrendo as diversas regiões da Armênia recolheu o que achou, tradicionalmente, ou. sob forma de canções populares, interessante para a sua História da Armênia.

Os homens que deram êsse impulso à renascença intelectual da nação, com suas obras literárias e traduções, foram chamados os tradutores.

O último rei armênio da dinastia dos arsácidas foi Artashês IV (422-428 a. C.).

4. Período: governadores armênios e estrangeiros (428-885). Por quatro séculos e meio, de 428 a 885, a Armênia ficou dividida em duas zonas de influência: a zona ocidental, governada por generais armênios, e a zona oriental, governada por sátrapas (64), alternativamente armênios e persas.

Desde a adoção do Cristianismo, a Armênia espiritual e intelectualmente voltou-se para o Bizâncio e através dela pa-. ra o Ocidente. Já pela sua posição geográfica, a Armênia era. uma frente contìnuamente aberta às guerras em prol de sua auto-defesa. Com a adoção de Cristianismo abriu-se mais uma

(64). - Sátrapa: têrmo iraniano, designando "governador de província do Im-.. pério". 
frente, por ser ela a vanguarda da civilização e dos ideais do Ocidente, nesta zona delicada da Asia Menor. Em conseqüência disso entrou a Armênia em choques contínuos com seus vizinhos do sul e do oeste. E foi assim que enfrentou uma guerra para a sua auto-defesa e para a defesa de sua religião.

Os políticos de Ctesifon (65), do Império iraniano, perceberam que a identidade dos ideais entre o Ocidente e os povos cristãos do Oriente Próximo, deveria trazer, inevitàvelmente, a interferência do Ocidente nos assuntos políticos do Oriente. Coisa bastante desagradável. Ctesifon tomou em conseqüência uma decisão: Unificação espiritual dos povos do Império iraniano dos sassânidas e de seus vizinhos, sob a égide da religião mazdeista e dêsse imenso bloco dos povos do Oriente Próximo fazer uma frente única para combater o Ocidente.

A realização do plano foi entregue a um homem fanático, o primeiro ministro do rei Azkerte, de nome Mihernerseh, que deveria começar com os armênios, como os mais representativos das inclinações ocidentais.

Em 450 foi enviado ao governador armênio um ultimatum do seguinte teor: aceitação da religião mazdeista ou morte e devastação total da Armênia (66) .

O governador militar da Armênia era o generalíssimo Vartan Mamikonian. Todos os chefes miiltares, políticos e religiosos da nação reuniram-se na capital Artashad e de comum acôrdo formularam e enviaram ao supremo chefe do Império persa, o rei Azkertes, o Resposta do povo armênio, cujo teor é difícil de ser encontrado nos anais das nações e que termina por dizer:

"Ninguém pode arrancar a nossa fé, nem os anjos, nem os homens, nem o fogo, nem a espada, nem a água, nem as torturas de qualquer espécie. Vossa espada, nosso pescoço".

Ao mesmo tempo os armênios enviaram uma delegação a Bizâncio, ao imperador Teodósio II, pedindo ajuda militar. Mas - "titular" da defesa do Cristianismo não quis intervir.

Nessas condições, no dia 26 de maio de 451, no vale de Avarayr, foi travada a histórica batalha de vida e de morte entre

(65). - Ctesifon: capital do Império persa, na Mesopotâmia, na margem oriental do rio Tigris.

(66). - Vide os historiadores armênios contemporâneos aos fatos: 1) Yeghishé, História da batalha do generalíssimo Vertan e do povo armênio. Veneza, ed. 1950. Tradução em francês, inglês, italiano e russo; 2) Ghazar Parbetzi, História de guerras de Vahan Mamikonian. Veneza, ed. 1933. Tradução em francês. 
fôrças desiguais, do povo armênio com 60.000 homens contra 300.000 soldados do Império iraniano, armados e reforçados com unidades de elefantes.

Naturalmente os armênios perderam a batalha. O generalíssimo Vartan e seus companheiros tombaram no campo de batalha, mas os sobreviventes retirarm-se para fortificações nas montanhas, e daí começaram a resistência passiva e ataques com formações de guerrilheiros. Esta resistência durou 32 anos e terminou com a vitória moral do povo armênio. O nôvo senhor do trono persa, o rei Vagharshês, compreendeu que com a fôrça bruta não poderia domar os sentimentos e princípios espirituais dos povos e que a coexistência pacífica com os vizinhos era melhor do que as guerrilhas inúteis.

Em 483 foi estipulado, entre o governador militar da Armênia, Vahan Mamikonian e o rei da Pérsia, Vagharshês, o acôrdo de livre culto da religião e da liberdade de consciência. Foram homens heróicos que com a própria morte salvaguardaram o futuro da nação.

Os arêmnios consideram a Batalha de Avarayr como o fato mais glorioso da sua História e um índice da fôrça moral da nação. Por isso, em cada ano, desde os tempos mais remotos, a data de 451 vem sendo comemorada em qualquer parte do mundo onde exista uma coletividade armênia .

Aqui vale, para a História Universal, uma comparação muito significativa entre dois fatos: quando no ano 451 os armênios com a efusão dos seus sangues defenderam a sua fé cristã, os três grandes representantes de Cristianismo: RomaBizâncio-Alexandria, com suas disputas religiosas ameaçavam quebrar a frente e a unidade cristã.

As conseqüências da política dos Imperadores bizantinos, imersos nas riquezas e "disputas bizantinas", foram funestas tanto para o Oriente, como para o Ocidente. Povos correligionários do Oriente Próximo foram deixados sòzinhos e cansados de guerras, não podendo defender "os acessos do Ocidente", não puderam resistir às hordas dos povos jovens, provenientes do sul (arábes) e do centro asiático (turcos seldjúcidas e osmanlis, tártaros e mongóis) que invadiram a Asia Menor e acabaram por tomar Constantinopla, "a porta do Ocidente".

A História Universal começou a mudar-se com o aparecimento no teatro mundial do elemento árabe. Vindos do sul desértico em 632, sob comando de dois chefes, um religioso, Maomé e outro militar, Omar, com uma cavalaria fenomenal, num relance desfizeram o Império persa dos sassânidas, pe- 
netraram nas fronteiras do. Império Bizantino, ocuparam o Egito, todo o litoral africano e pelo estreito de Gibraltar passaram para a Espanha, e se aproximaram pelo sul e pelo oeste do Mundo Ocidental. Em 642 o general Moávia chegou mesmo às portas de Bizâncio, mas a fortaleza dos Imperadores ainda era forte e pôde resistir.

Em 642 (6 de outubro), o general árabe Habib ocupou a capital da Armênia, Tuvin nesta época, e desde esta data até 885, a Armênia passou para a zona de influência dos árabes, sob a forma de tributária, com 400.000 talentos de prata anuais, de cavalos e de uva-passa. Ela foi governada por chefes nacionais, às vêzes também árabes, de nome "Vosdigam". De 885 a 1064 o sentimento da liberdade levantou-se e foi restaurado o Reino armênio sob a dinastia dos bagrátidas, permanecendo, entretanto, fiéis à aliança com os árabes.

$$
\text { : }
$$

\section{Período: dinastia dos bagrátidas (885-1064) .}

O domínio dos árabes começou enfraquecer com o aparecimento na Ásia Central de um nôvo povo, os turcos seldjủcidas, de instinto bárbaro, que cometeram atrocidades até então desconhecidas.

Desde a introdução de Cristianismo a Armênia era governada por homens de uma das quatro famílias da aristocracia armênia, que tiveram em suas mãos os destinos da nação, sendo a primeira e a mais importante a família dos Mamikônidas, a segunda dos Siunis, a terceira dos Bragátidas, e a quarta a dos. Ardzrúnidas.

Nesse período os chefes da nação eram os bagrátidas.

O governador bagrátida, Ashod, aproveitando a fraqueza dos árabes e com o apôio moral do imperador de Bizâncio, de origem armênia (67), restaurou o regime monárquico. O emir (68) de Bagdá (69) considerando útil, no momento, a amiza-

(67). - Basílio I - Nâo se pode ter uma visão completa da História Bizantina sem o conhecimento da História do povo armênio, pois êste forneceu ao trono de Bizâncio 8 imperadores e imperatrizes. Estes imperadores foram: 1) Morik (Maurício), 2) Leão III, o Iconoclasta, 3). Leão V, 4) Teófilo, 5) Basílio I, 6) Constantino Porfirogêneta, 7) João Tzmisces, 8) Basílio II. Cf. P. G. Der Sahakian. Os imperadores armênios de Bizâncio, 2 vols. Veneza, 1905, 1927; H. Asdourian, op. cit., págs. 103-104.

(68). - Amira, têrmo árabe designando "governador".

(69). - Bagdá, capital do Império muçulmano, construída pelo califa El-Mansur ou Jafar, nos anos de 762-766, na Mesopotâmia, num ângulo do rio Tígris; H. Asdourian, op. cit., pág. 178. 
de dos armênios, concordou e o imperador de Bizâncio, Basílio I, enviou-lhe a corôa real.

Os reis armênios desta dinastia foram os restauradores do país. O rei Abas (928-952) reformou a cidade de Cars; Ashod III (952-977) fundou a cidade de Ani, como a capital do nôvo reino, com palácios e igrejas de estilo tipicamente nacional; Sempad II (977-990) fêz construir a catedral e as muralhas da nova capital pelo famoso engenheiro armênio Tiridates, que posteriormente foi chamado pelo imperador do Bizâncio para a restauração da catedral de "Santa Sofia", obra colossal do imperador Justiniano; Kakig I (990-1020) foi protetor das ciências e das artes e do comércio com o exterior; construiu tantas igrejas que é do seu tempo a locução proverbial e de uso popular de jurar sôbre as "mil e uma igrejas de Ani".

Os turcos seldjúcidas estavam às portas da Asia Menor sob o comando de Tukril (1038-1063), saqueando, destruindo e queimando o que achavam na sua passagem. Os imperadores de Bizâncio, em vez de enfrentar o perigo comum, quiseram aproveitar-se da ocasião e tentaram ocupar a capital da Armênia, Ani, mas por duas vêzes foram derrotados.

Os armênios, apunhalados pelas costas, humanamente não poderiam conter os intermináveis bandos seldjúcidas que em 1048 avançaram sôbre a Armênia. As cidades armênias, depois da cidade de Cars, chefiada pelo intrépido general Tatul, combateram heròicamente, mas cederam por falta de abastecimento. E' do general Tatul o famoso incidente entre êles e o chefe turco.

"Se o golpe é meu, o filho do general turco não sobreviverá", e não sobreviveu.

No dia 6 de julho de 1064 a capital da Armênia, Ani, caiu nas mãos dos turcos de Alp-Aslan, sucessor de Tukril, e foi incenciada. A queda de Ani significou o fim do Reino armênio em território nacional e o início das emigrações em massa do povo armênio para o estrangeiro.

As emigrações começaram já desde o VII século, devido à invasão árabe, para o interior da Ásia Menor. Um grande srupo de armênios instalou-se na ilha de Creta no ano de 961. Foi depois da queda e incêndio da capital Ani que as emigrações tornaram-se maciças. Centenas de milhares de armênios emigraram para Bizâncio (grande centro cosmopolita), para as cidades litorâneas e ocidentais da Anatólia (Asia Menor), para os países do Ocidente (Polônia, Hungria, Transilvânia, Itália), para o Egito, para a Terra Santa, e para as alturas dos montes 
Taurus, na Cicília, onde logo se surgirá um nôvo Reino armênio $(70)$.

\section{Período: a dinastia dos rubênidas e o Reino armênio da Cilícia (1080-1375).}

A Cilícia, antes da chegada em massa dos armênios, era um território pràticamente livre. Desde tempos remotos já encontramos aí elementos armênios. No ano de 362 o imperador Juliano "o apóstata", fêz martirizar um padre armênio, Estêvão de Ulni (71), venerado como santo. No ano de 404 o bispo grego João Crisóstomo, encontrou armênios na cidade de Kokison.

Em 1071 o imperador de Bizâncio, Romano IV, chegou ao Oriente para enfrentar os turcos. $\mathrm{Na}$ batalha de Melazkert êle foi derrotado e o seu general Pilardus, de origem armênia, transferiu-se para a Cilícia, criando aí uma administração independente, escolhendo a cidade de Marash (Germanicus) como centro.

O pequeno grupo dos amantes da liberdade e da independência aumentou dia a dia com novas migrações armênias. E assim nasceu, nas alturas dos montes Taurus um nôvo reino armênio, o Reino da Cilícia, cujo fundador era um homem valoroso, de nome Ruben, da cidade de Sassun. Devido ao seu nome tôda a dinastia reinante passou a chamar-se rubênida. A bandeira do nôvo reino tinha um leão com fundo vermelho.

A primeira fase do nôvo Estado armênio (1080-1178, Ruben I - Ruben II) foi sob forma de Principado, sendo os chefes do Estado "príncipes ou barões", sendo que êste último título foi-lhes atribuído pelos cruzados do Ocidente. Na segunda fase (1188-1375, Leão I - Leão V, Lousinian) o Estado funcionou sob a forma de monarquia.

O Reino da Cilícia, nas suas formas administrativas e sociais, foi de tipo ocidental, desde a sua criação, pois coincide com a chegada ao Oriente Próximo das Cruzadas Ocidentais, que foi o grande acontecimento dêste período e a invasão de novos povos bárbaros: turcos, tártaros e mongóis, vindos da Asia central e do Oriente remoto.

(70). - H. Asdourian, op. cit., pág. 205.

(71). - Ulni: antigo nome da atual cidade de Zeitun. 


\section{As Cruzadas.}

Conhecemos a história das Cruzadas. Aqui vamos expor, brevemente, a parte referente aos armênios $e$ as conseqüências que elas tiveram para êsse povo.

Os turcos estavam às portas de Bizâncio, na pequena cidade de Nicéia. O imperador Aleixo I Comneno pediu ao $\mathrm{Pa}$ pa o auxílio dos cristãos do Ocidente.

A I Cruzada, composta de 300.000 homens, sob o comando de Godofredo de Bouillon, chegou a Constantinopla e os turcos foram derrotados. Os cruzados enviaram uma delegação a Constantino I, pedindo a cooperação dos armênios da Cilícia. Constantino I ordenou que o general Bagarat, com um exército armênio, fôsse ao encontro dos cruzados para conduzi-los, através de difíceis passagens da Cilícia, até às planícies da Síria, dando, ao mesmo tempo, ajuda em abastecimentos, armas e cavalos.

As Cruzadas tiveram três conseqüências para o Reino armênio da Cilícia: social, cultural e política:

a). - Social. A côrte real, os costumes e a administrxção foram modelados pelo tipo ocidental. Foram adotados títulos ocidentais como: barão-baronesa, príncipe-princesa, marquês, marechal, condestável, chanceler, duque, senescal, cavaleiros, etc. Foram adotados os códigos dos tribunais ocidentais (72).

Começaram então relações e casamentos entre ocidentais e orientais. O movimento comercial aumentou nos portos da Cilícia (Ayas, Payas...), sobretudo com as repúblicas italianas (Gênova, Veneza, Ravena...) e com os árabes.

Começaram também, como era hábito na época, as disputas religiosas, a respeito dos têrmos teológicos e dos concílios ecumênicos, e surgiram questões entre os partidários de Roma e Bizâncio. Os missionários ocidentais abusaram de suas funções, aproveitando-se da presença dos exércitos dos cruzados; interferiram, de modo arbitrário, em assuntos internos do govêrno, interferência essa que não foi agradável para o país que lhes dera a mais ampla e leal hospitalidade. As conseqüências foram deploráveis.

b). - Cultural: a conseqüência cultural mais importante foi a divulgação e o estudo das línguas ociddentais: latim, francês, italiano, alemão, que eram necessárias para as relações

(72). - Vide Ansizk de Antioquia do Condestável Sembad. 
comerciais, sociais e literárias. Por causa dos casamentos mistos, os consortes foram obrigados a estudar as suas respectivas línguas.

Apresentou-se, assim, o caso da fonética do alfabeto armênio que composto como era de 36 letras, adotou, nos séculos $\mathrm{X}$-XII, mais duas letras (as duas últimas, O-F), para dar possibilidade aos próprios armênios de pronunciarem as novas palavras adotadas e aos estrangeiros para facilitar o estudo e os fonemas do armênio.

c). - Política. A presença dos cruzados na Armênia não foi feliz, foi mesmo funesta para a soberania nacional da Armênia, por causa da mentalidade e da maneira de agir dos guerreiros que, com honrosas exceções, chegaram ao Oriente com outras finalidades.

Desde os tempos remotos, para os homens do Ocidente, o Oriente sempre teve um lado misterioso, dum paraíso não conhecido. Os reis e o povo da Cilícia armênia, com uma boa fé de aliado leal, prestaram o mais precioso serviço aos exércitos das Cruzadas, colocando à sua disposição abrigos, palácios, casas, fazendas, víveres em abundância, armas e cavalos, além da assistência em informações topográficas. Mas, infelizmente, perceberam os armênios nesses homens um espírito aventureiro, cheio de interêsses individuais e prazeres pessoais, de predadores de terras dos particulares. Para muitos dos cruzados era preferível ser dono, no Oriente, dum palácio, duma fazenda, duma cidade do que arriscar a própria vida para libertar a Terra Santa.

Para atender as suas ambições, muitos chefes das Cruzadas não hesitaram em cometer atos de injustiça, de violência e de traição contra os armênios que lhes prestaram ajuda e lhes deram cordial hospitalidade. Foram os aventureiros cruzados que criaram dificuldades internas para o país, desorganizaram o seu dispositivo defensivo, enfraqueceram as fôrças armadas e apressaram o fim do Reino armênio da Cilícia.

O Reino armênio da Cilícia durou cêrca de 30,0 anos e êsse foi o período mais longo da independência armênia, a melhor página da sua História e sob o ponto de vista cultural, o "século de prata".

Os reis mais insígnes dêsse reino foram: Ruben I (10801095), Toros II (1144-1168), Leão I (1187-1218) (73), Hetum I

(73). - Leão I é o primeiro rei armênio que mandou cunhar moedas em ouro, prata e cobre, com inscriçóes armênias. Dêle restou um documento com seu autógrafo. Cf. H. Asdourian, op. cit., pág. 274. 
(1224-1269), Leã̃o II (1269-1289) e Leão V Lousinian, último rei armênio (1374-1375) .

A Ásia Central e o Oriente Remoto são os fornecedores intermináveis de povos, sempre em busca das planícies férteis do Oriente Próximo.

Depois dos turcos seldjúcidas foi a vez dos tártaros da Mongólia (capital Karakorum) (74) que, chefiados pelo famigerado Gengiscão (1206-1227), avançaram para a Ásia Menor depredando e queimando as vastas regiões do Irão, da Mesopotâmia, destruindo o que fôra construído pelas civilizações persa e árabe e acabaram por se instalar no centro da Asia Menor. Sucederam-lhes os memlúcidas do Egito, que conquistaram a Palestina, a Mesopotâmia e parte da Asia Menor.

O govêrno da Cilícia de um lado deveria enfrentar as dificuldades internas, criadas pelas Cruzadas, e do outro enfrentar os ataques dos bandos bárbaros. Enfraquecido em armas, em homens e em finanças, o reino acabou por ceder.

A capital do reino, Sis, depois de resistir por quatro meses (5 de janeiro-abril de 1375) foi tomada pelas fôrças egípcias. O último rei da Cilícia, Leão $\mathrm{V}$ Lousinian e a família real foram conduzidas ao Egito, onde os representantes da coletividade armênia, funcionários da côrte do sultão, providenciaram uma residência confortável para a família real. A rainha Maria faleceu no Cairo e o rei Leão $\mathrm{V}$, por intervenção do rei de Castela, deixou o Egito rumando para a Europa em busca de ajuda, para a libertação da Cilícia, mas seus esforços foram em vão. Os últimos onze anos da sua vida errante passou-os na Europa, na maior parte em França, onde o rei Carlos VI destinou-lhe um dos palácios reais.

O último rei da Armênia, Leão V Lousinian morreu em Paris, no dia 29 de novembro de 1393 . Foi enterrado na Igreja dos religiosos Celestinenses. Seu corpo repousa sob um túmulo de mármore prêto, sôbre o qual se ergue sua estátua em branco, com a seguinte epígrafe:

(74). - Hetum I viajou até a capital da Mongólia, perto do Himalaia, para encontrar-se com o chefe dos tártaros e mongóis, Manku-Khan, em 12541255, para negociar uma aliança de amizade. Do rei Hetum nos ficou um cetro em topázio, inteiriço, com tamanho de cêrca de $70 \mathrm{~cm}$., que se conserva no museu do mosteiro armênio de São Tiago (Surp Hagop) em Jerusalém. 
"Aqui repousa o nobre e digno príncipe Leão Lousinian V, rei da Armênia, que morreu em Paris no ano 1393. Rezai por êle" (75).

Com a morte do seu último rei, o Reino armênio da Cilí-. cia deixou de existir para sempre. Assim, as duas Armênias, a Armênia Maior (a dos três lagos) e a Armênia Cilícia, ficaram entregues ao seu destino, sem dono, sempre a enfrentar novos pretendentes à sua posse.

Da Asia Central chegaram novas tribos de turcos mongolóides e osmânidas, encabeçados por Lenk-Timor (ou Tamerlão), cujo aspecto físico fazia tremer e cujo maior prazerera matar as mulheres, ligando-as pelos cabelos às caudas dos seus cavalos, e beber o sangue humano nos crânios dos homens (76).

Mais de quinze historialdores armênios, contemporâneos. dos fatos, descreveram o que aconteceu no país, no decurso.

(75). - H. Asdourian, op. cit., pág. 321. A espada do rei Leão V Lousinian con-. serva-se no museu armênio de São Lázaro, dos padres mequitaristas, em Veneza.

(\%6) . - Nota sôbre o têrmo turco: Já que mostramos até onde chegaram os tur-. $\cos$ e do que foram capazes de fazer, permitimo-nos dar algumas explicações de utilidade pública.

Desde os tempos mais remotos todos os emigrantes orientais (armê-.. nios, sírios, libaneses) vindos ao Brasil eram chamados de turcos por. parte do público brasileiro, pela simples razão de que os países de pro-. cedência (Ásia Menor, Síria, Líbano, Palestina, Egito) naquela época: achavam-se sob o domínio dos turcos otomanos.

o Império otomano desagregou-se depois da 1.a Guerra Mundial, mas. - apelido inđistinto "từco", històricamente e etnològicamente errôneo,. e moralmente desagradável, continuou e continua ainda nos nossos dias, se bem que com menor insistencia, a designar os imigrantes do Próxi-mo Oriente, que nāo têm nada em comum, nem sob o ponto de vista racial, nem cultural, com o "povo turco", sendo os primeiros de origem indo-européia ou semitas, elementos trabalhadores e contribuidores do. desenvolvimento e da civilizaçāo universal, enquanto que os segundos,.. "os turcos são os mais desviados da raça amarela, de tipo mongolóide", de instintos bárbaros, depredadores e destruidores dos seculares monumentos artísticos e históricos da civilização dos outros povos. Onde dominaram, os turcos nada construiram e destruiram aquilo que os outros. lizeram.

Desde a sua origem até hoje em dia, o turco nada deu à humanidade, nada fêz para a civilizaçāo e em nenhum setor teve e não tem: nenhum representante.

$E^{\prime}$ preciso acabar com a atribuição irônicamente injusta dêsse đesagradável apelido "turco" a respeito dos "povos orientais", e depois detomar conhecimento dos dados etnográficos, históricos e geográficos, e dos atos bárbaros e criminosos inigualáveis e indiscritíveís dos "turcos" contra a humanidade, contra a civilização e contra a consciência universal, cujo último exemplo é o do ano 1915. E' justo concluir: que - turco só é êle mesmo, geração daqueles que "beberam o sangue hu. mano com os crânios dos homens". 
de sete séculos (do VIII ao XV). Em muitos casos, são as únicas fontes de informações que possuímos (77).

A começar de 1400 , tôda a Asia Menor foi teatro de guerras de competição, entre bandos persas, tártaros, mongóis, egípcios, turcos seldjúcidas e turcos osmânidas. Os últimos foram predominantes e se assenhorearam de quase tôda a Ásia Menor. Seu chefe, o sultão Mohamed Fatih I, no ano de 1453, com uma poderosa fôrça armada terrestre-naval ocupou Constantinopla. Foi o maior golpe para o Ocidente, e Bizâncio sofreu a conseqüência da sua política quietista.

O sultão Mohamed I tomou o maior cuidado com o elemento armênio do seu império, por ser êle o mais trabalhador em todos os setores. Seu médico pessoal era um armênio, Amirdovlat, da cidade de Amásia, versado em ciências médicas árabes e orientais. (78). O sultão Mohamed I instituiu o Patriarcado Armênio de Constantinopla, no ano 1461, para eliminar as interferências das potências estrangeiras nos assuntos internos do país, sob o pretexto de resolver os problemas religiosos das "minorias cristãs" no seu império (79).

O desmembramento da Armênia começou.

Depois do ano 1500, os persas com Shah-Abas invadiram as regiões sul-orientais da Armênia e transfęriram daí para a Pérsia mais de 100.000 habitantes, para reconstruir o seu país. Os armênios estabeleceram-se na capital Isfahan e na cidade Nova Tchula, fundada por êles. Outros grupos partiram para mais longe, a India, estabelecendo-se nas cidades de Bombaim, Calcutá e Madras.

Em 1700, na parte dominada pelos persas, começou um movimento de libertação, encabeçado por Israel Ory e David Pek. Foi criada então a Confederação das Cinco Provincias (Karabagh), com autonomia local .

A Rússia dos tzares também, com Pedro-o-Grande (16821725), começou a interessar-se pela Armênia. No ano 1827 os russos ocuparam a província de Erivan e a sede patriarcal de

(77). - Ghevont Yeretz (VIII século), Hoyanes Traskhanakertzi (X), Thomas Ardzruni (X), Sdepanos Asoghik (XI), Arisdakes Lasdiverdtzi (XI), Matheus Urhayetzi (XII), Samuel Anetzi (XII), Mekhitar Anetzi (XIII), Vanagan Vartabed (XIII), Kirakos Kantzaketzi (XIII), Vartan Areveltzi (XIII), Maghakia Abegha (XIII), Mekhitar Ayrivanetzi (XIII), Sdepanos Orbelian (XIV), Thomas Medzopetzi (XIV-XV). Este último é testemunha ocular dos fatos horriveis que se desenrolaram no país durante a invasão das horđas de Lenk-Timor. Cf. H. Asdourian, op. cit., págs. 206210, 322-330; Arakel Arakelian, História da evoluçáo intelectual-culturał do povo armênio, Yerevan, 1959, págs. 460-482.

179). - H. Asdourian, op. cit., pág. 387 . 
Etchmiadzin. Com o decreto "Bologenia" do Tzar, a Igreja Armênia passou para a administração russa (80). No ano de 1878 ( 2 de março), com o artigo 16 do Acôrdo de Santo Stefano, entre a Rússia e a Turquia, a Rússia tomou sób sua proteção o norte da Armênia. Começou uma forte corrente emigratória em direção da Rússia (Criméia, Batum, Odessa, Moskova), da Geórgia (Tiflis) e do Azderbeijan (Bakú, a cidade petrolífera).

No mesmo ano de 1878 (de 13 de junho-13 de julho), na reunião de cúpula de Berlim entre as grandes potências (Rússia-Turquia-Inglaterra-Austria-Alemanha-França), por solicitação da delegação inglêsa, foi introduzido no Acôrdo Geral o Artigo Único 61 (substituindo o "Artigo 16"), com o qual o govêrno turco (sendo sultão o famigerado Hamid), se encarregava a fazer reformas nas províncias armênias sob sua dominação. mênios.

Tudo jôgo dos políticos, ilusões e decepções para os ar-

O espírito de independência, porém, não lhes faltou nunca, como não faltaram a resistência dos mais corajosos, nas alturas montanhosas da Armênia Maior e sobretudo na Cilícia, onde algumas das suas cidades (Zeitun, Hadjin, Musa-Dagh, etc.), até o ano de 1915, gozaram duma semi-autonomia.

Chegou a Primeira Guerra Mundial. Nos anos de 19151918, os governantes turcos, aproveitando-se do caos geral, escreveram para a História Universal a página mais vergonhosa de atrocidades cometidas nas cịdades armênias da Asia Menor. Os emigrantes armênios povoaram os quatro cantos do mundo, principalmente a Síria, Líbano, Iraque, Bulgária, Grécia, França e as duas Américas.

Com o Armistício, o Império Otomano foi desmantelado e no dia 28 de maio de 1918 a Armênia tornou-se República Livre. O tempo da liberdade, porém, foi breve.

No ano de 1920 (no dia 29 de novembro) a Armênia caiu sob o poder dos exércitos de Lenin, e tornou-se uma das Repúblicas Socialistas da União Soviética.

A história do povo armênio entrou numa fase nova, que continua, como continua também a sua evolução até encontrar a sua forma final.

Esta nova fase é História Contemporânea, e cabe aos pósteros julgá-la :

(80). - Inspirando-se nas mesmas razões que conduziram o sultão da Turquia, Mohamed I, a instituir o Patriarcado Armênio de Constantinopla. 


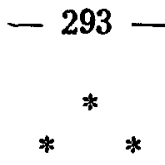

Vimos, resumidamente, a História de um pequeno povo, o armênio, que orgulha-se de sua antigüidade de mais de trinta séculos (desde 1200 a. C.), que viveu num setor delicado da Asia Menor, numa Pátria sujeita às guerras contínuas, por ser sua posição geográfica uma "encruzilhada" que serviu de rota de trânsito de diversos povos e ponto de choque entre o Ocidente e do Oriente. A causa de tôdas as suas desgraças foi a de estar no caminho dos grandes impérios, na charneira das civilizações rivais e de ideologias opostas.

A Armênia teve, como vizinhos, povos e impérios numèricamente e materialmente superiores a ela, com os quais teve relações históricas, culturais e comerciais, e muitos dêles estão hoje desaparecidos da face do mundo e o povo armênio, apesar de suas desvantagens e de sua inferioridade numérica e os acontecimentos trágicos da sua História moderna, sobreviveu e continua com dignidade sua existência no mundo civilizado, tendo representantes dignos em cada setor das ciências e da arte e até nas mais altas esferas do mundo atômico.

YESSAI OHANNES KEROUZIAN

Professor da Cadeira de Língua e Literatura Armenia da Faculdade de Filosofia, Ciências e Letras da Universidade de São Paulo. 